\title{
Future Climate Impacts in Woodland and Forest Steppe Based on Holocene Paleoclimatic Trends, Paleobotanical Change in Central Part of the Carpathian Basin (Hungary)
}

\author{
Katalin Náfrádi ${ }^{1}$, Gusztáv Jakab ${ }^{2}$, Pál Sümegi ${ }^{1,3}$, Zoltán Szelepcsényi ${ }^{1}$, Tünde Törő́csik ${ }^{1}$ \\ ${ }^{1}$ Department of Geology and Paleontology, University of Szeged, Szeged, Hungary; ${ }^{2}$ Szent István University, Szarvas, Hungary; \\ ${ }^{3}$ Hungarian Archaeological Institute, Budapest, Hungary. \\ Email: nafradikata@gmail.com
}

Received January $23^{\text {rd }}, 2013$; revised February $24^{\text {th }}, 2013$; accepted April $15^{\text {th }}, 2013$

Copyright (C) 2013 Katalin Náfrádi et al. This is an open access article distributed under the Creative Commons Attribution License, which permits unrestricted use, distribution, and reproduction in any medium, provided the original work is properly cited.

\begin{abstract}
The Sirok Nyírjes-tó peat bog provides an almost full Holocene climatic record reconstructed by bog surface wetness investigations based on plant macrofossil analysis. We compared our macrofossil data to anthracological material derived from archaeological sites and to the newest bioclimatological models of the Carpathian basin. On the basis of environmental historical and climatic data we aimed to reconstruct the expected changes of forested areas in the Carpathian Basin. The results indicate that the surface wetness decreases in long term. Parallel to the Sphagnum-peat decline an open forest and forest steppe developed surrounding the bog. The complete disappearance of Sphagna from the area must be linked to a steady drop in rainfall, resulting in at least $50 \mathrm{~mm}$ deficit in the local water balance. This could have been achieved by an increased evapotranspiration as a result of elevated temperatures of the summer growth season. This deficit value must have exceeded even $100 \mathrm{~mm}$ during the Middle Holocene Transition.
\end{abstract}

Keywords: Carpathian Basin; Climatic Change; Forest Transformation; Paleoecological Data

\section{Introduction}

One of the most important features of the recent vegetation of the Carpathian Basin (Figure 1) is that both the upper (according to height) and the lower (according to drought) timber-line [1] as well as the transitional (ecoton) vegetation between the open and closed vegetation that developed behind the timber-line can be found in the area. Because of human impact [2] and environmental effects showing mosaic patterning [3] these boundaries and the ecoton zones indicate not a clear border rather a mosaic system in the basin and in the mountainous region surrounding the basin [3]. Thus the current and the prospective, modeled climatic changes [4] might have an important effect on the transitional zone of the open and closed vegetation, on the ecoton zone behind this boundary and on the forested areas in the mountainous region and the basin [5].

The ongoing climatic changes probably cause significant alterations in the forests of the Carpathian Basin [5]. It is hard to model these changes by recent climatic and vegetation data because there are data sets of only a few decades to model these alterations. Furthermore, on the basis of the palaeoecological and palaeoclimatological data until now the vegetation and climatic changes show a strong regional and local trend due to the mountainous zone in the Carpathian Basin. Consequently these changes differ from the global trends $[3,6]$.

We aimed to reconstruct the Holocene climatic changes and vegetation cover, as well as to compare the obtained results to climatic models. Therefore we chose a small Sphagnum bog (Sirok, Nyírjes-láp) for study site [7-9] that is located at the lower timber-line, on the transitional zone of the Pannonian forest steppe and the forested areas of the Carpathians. This area is suitable for pollen and macrobotanical analysis so the local changes are provable. The palaeobotanical samples were derives from an undisturbed core with radiocarbon data. As a result of macrobotanical analysis of samples it was possible to create a model to detect climatic and vegetation changes for the prospective alterations, as well as the changes of forest ecosystems in the study area. We compared our data to anthracological material derived from archaeological sites [10] and to the newest bioclimatological models of the Carpathian Basin [11,12]. On the basis of 
environmental historical and climatic data we aimed to reconstruct the expected changes of forested areas in the Carpathian Basin.

The bog of Sirok is unique in Hungary. One of the most popular approaches is looking for proxies reflecting transformations in the biological and chemical composition of peat sequences as signals of past climatic fluctuations. A frequently used approach in chemical analysis is the investigation of humification $[13,14]$. This approach relies on the logic that surface humidity ultimately determines the rate of decay of plant matter. When peatlands are dried out, this is reflected in a sudden increase in humic acids within the deposits. These acids are extracted from the deposits using various alkalis and their concentration is determined in the solution by spectrophotometric approaches. The most widely adopted method in the analysis of biological components is the study of plant macrofossils, including mosses or testacea [15-19]. These studies enable us to identify various peatland types and past communities. However, there is a special feature of peatland plants that can aid the interpretation of earlier environmental conditions. Certain species are distributed along a gradient reflecting differing water depths. Bog surface wetness investigations using the QLCMA technique (semi-quantitative quadrat and leaf-count macro- fossil analysis technique) of Barber et al. [20] permitted high-resolution reconstruction of past climatic changes. Former bog surface wetness studies aimed at deciphering past climatic conditions via detailed analysis of peatland deposits, primarily focusing on the investigation of Sphagnum peat from so-called ombrotrophic peatlands $[16,17$, $1-23]$.

Climatic conditions favoring the evolution of these type of peatlands are mainly restricted to the western parts of Europe under oceanic climatic influence [17,24] or in Fennoscandinavia [25], where the moisture gradient is unambiguously reflected in the distribution of certain Sphagnum taxa; no discussion, however, occurs on SE Europe, including Hungary. Barber and Charman [17] questioned the suitability of strongly continental peatlands for paleoclimatic reconstructions. This area appears blank on the data source maps, pointing to the paucity of available Holocene bog surface wetness records in this region [26].

The general climatic characteristics of Hungary are far from ideal for the emergence of Sphagnum peatlands. The majority of Sphagnum peatlands are restricted to the northern areas of the North Hungarian Range and the northern Great Hungarian Plain (GHP), as well as the eastern parts of the country enjoying more precipitation

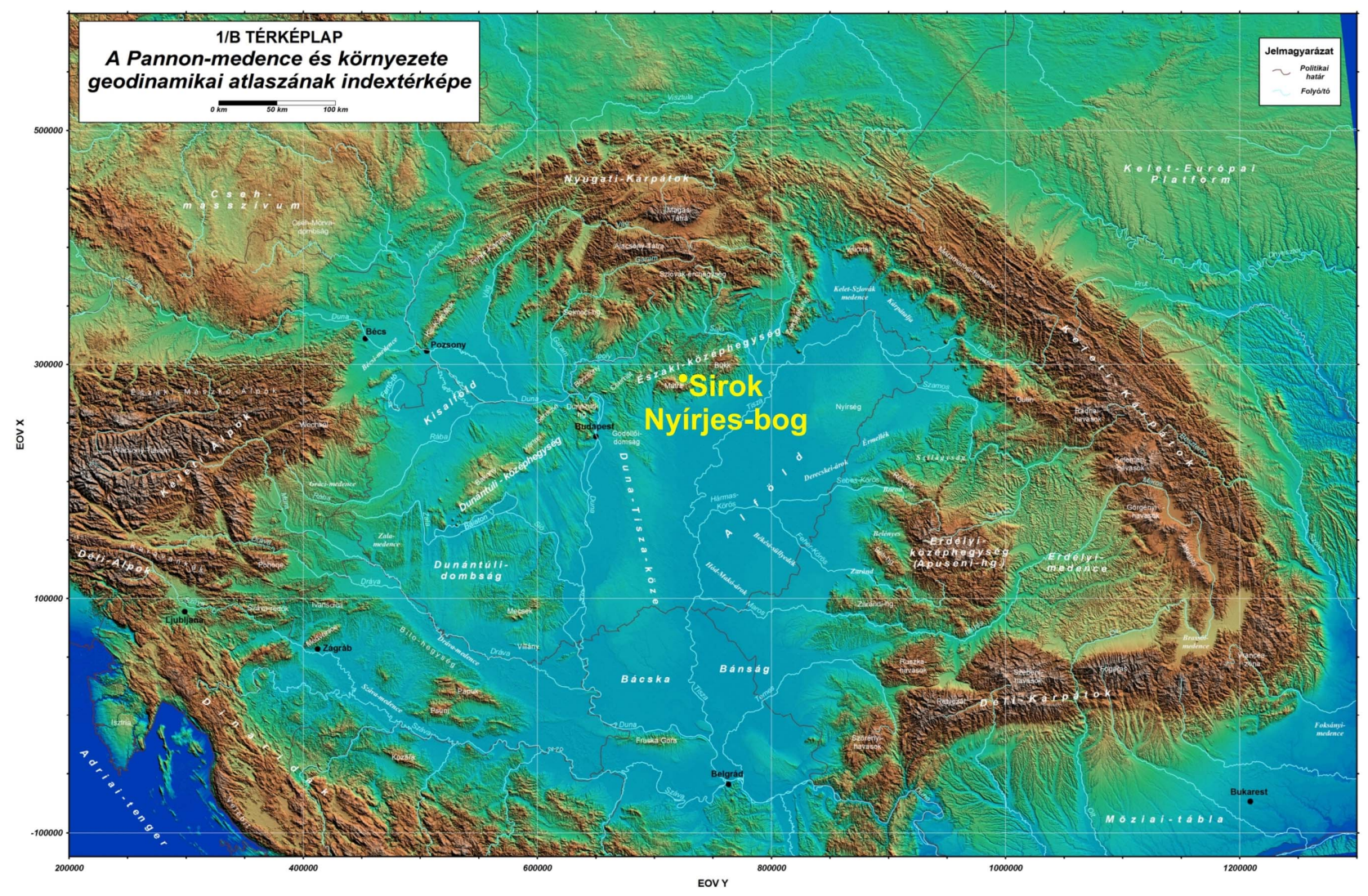

Figure 1. Location of Sirok Nyírjes-bog in the Carpathian basin (source: geophysics.elte.hu/atlas/geodin_atlas.htm). 
thanks to the positive effect of the oceanic and montane climatic influences $[27,28]$. Climatic influences characteristics of the Köppen type steppe zone (BS) [29] are traceable in the heart of the Carpathian Basin alone and appear with a frequency of 2 - 3 times during a decade. Furthermore, their development is by no means regular and cyclical but rather sporadic [30]. So by using the Köppen type climate classification system, the area of the Carpathian Basin falls mainly into the category $\mathrm{Cfb}$ (warm temperate fully humid with warm summer) and subordinately into $\mathrm{Cfa}$ (warm temperate fully humid with hot summer). The marginal hilly and montane areas within analysed Nyírjes bog at Sirok belong to the category D (snow zone) according to this system [12]. Conversely, in order to better highlight the climatic background of the forest-grassland ecotone system, which is present in the heart of the Carpathian Basin, the vegeta- tion classification system of Holdridge [31,32] is better suited than the climate classification system of Köppen $[12,33]$. According to the modified Holdridge classification (Figure 2), the major part of the basin is put to the transitional category found between those of cool temperate steppe, cool temperate moist forest and warm temperate dry forest, where the first (steppe) and the last categories (dry forest) also turn up climatically in the form of scattered patches. This grassy area forming an ecotone between the actual grasslands and dry and humid woodlands corresponds to the Pannonian forest-steppe vegetation of the Great Hungarian Plains while the on the foothill, hilly and mountainous region covered by woodland (Figure 1). The ratio of the evapotranspiration and precipitation (Figure 3) is essential in separating forested and ecoton areas so primarily we aimed to model the alterations of these factors.

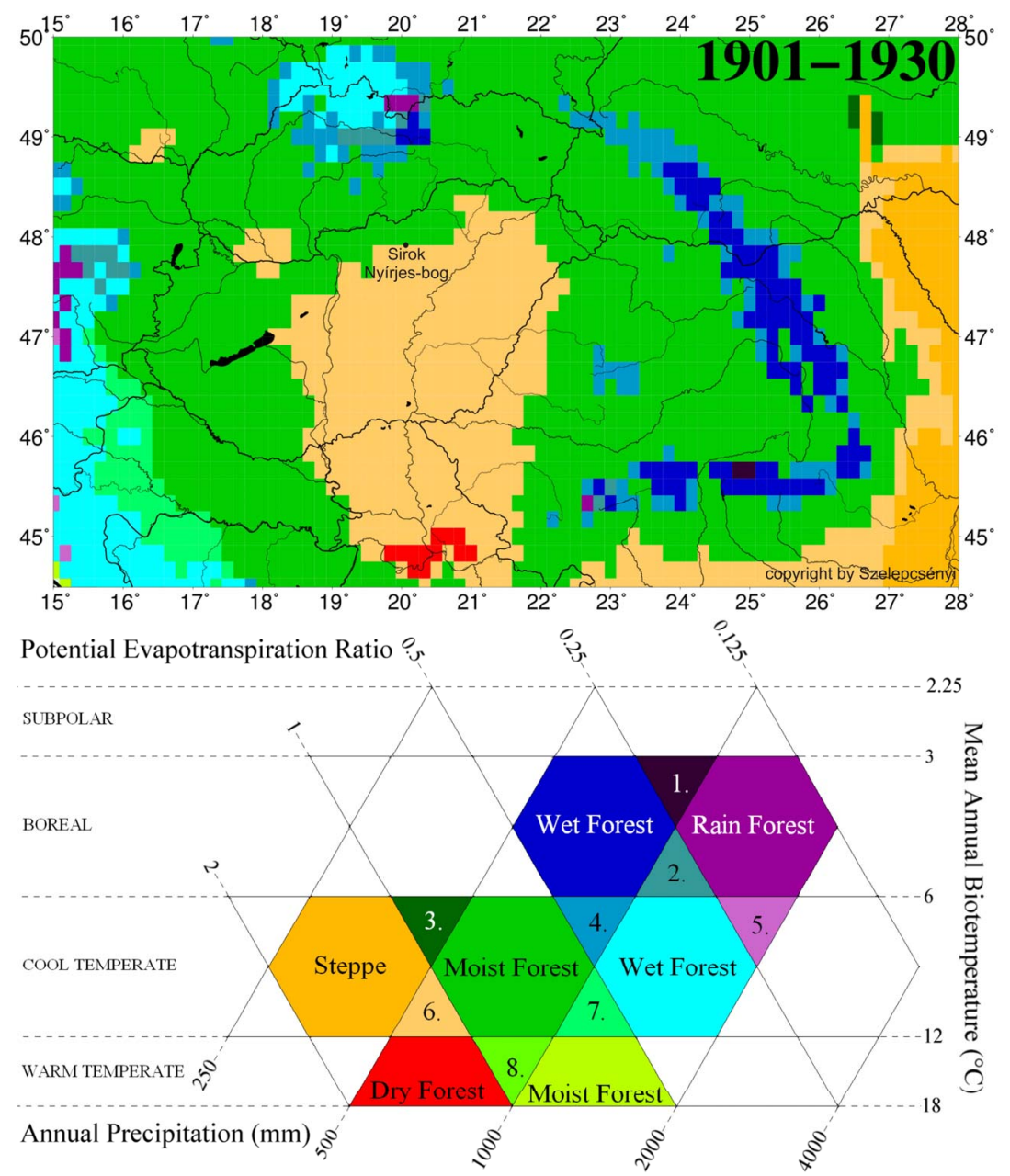

Figure 2. The spatial pattern of life zones at the beginning of 20th century (1901-1930) in Carpathian Basin for the modified Holdridge life zone classification [33] for the database CRU TS 1.2 [34]: 1) Boreal superhumid wet-rain forest; 2) Boreal perhumid wet-rain forest; 3) Cool temperate humid forest-steppe; 4) Cool temperate perhumid moist-wet forest; 5) Cool temperate superhumid wet-rain forest; 6) Cool temperate subhumid forest-steppe; 7) Cool temperate humid moist-wet forest; 8) Warm temperate humid dry-moist forest. 


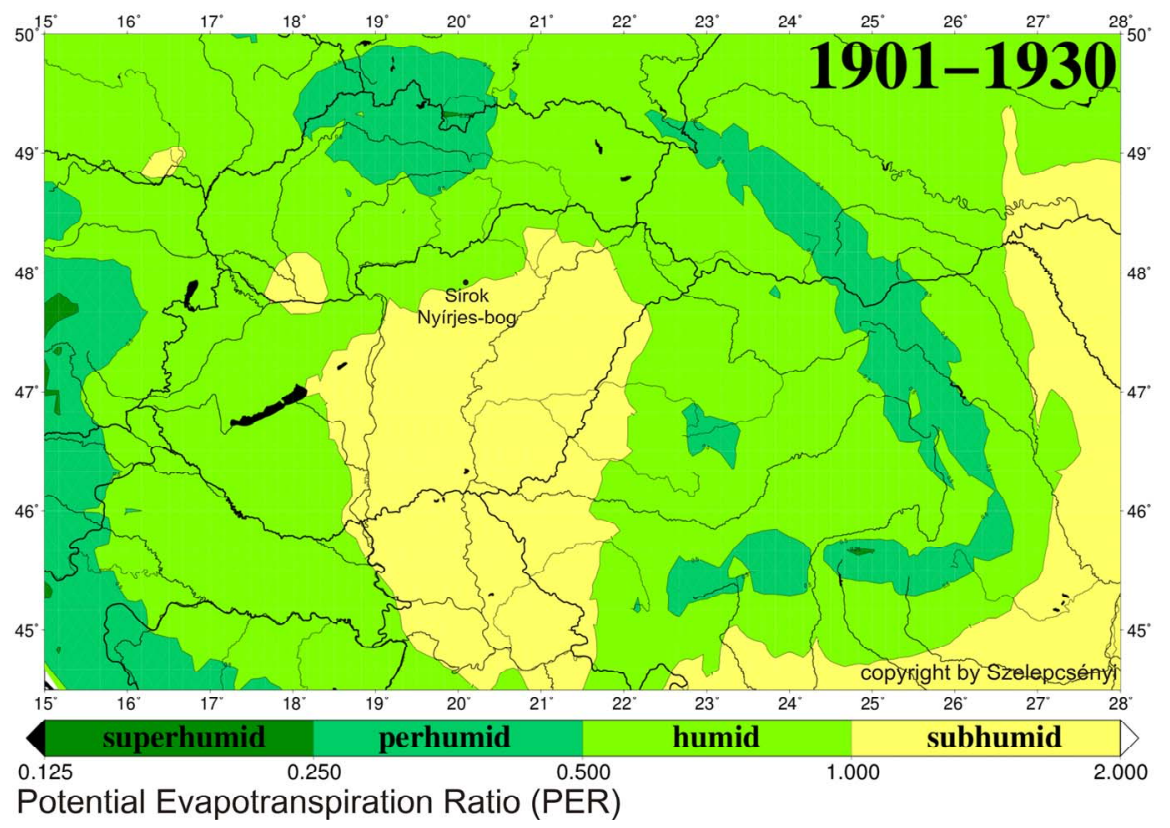

Figure 3. The humidity provinces at the beginning of $20^{\text {th }}$ century (1901-1930) in Carpathian basin for the potential evapotranspiration ratio (PER) for the database CRU TS 1.2 [34].

\section{Study Area}

The location of the Nyírjes-tó peat bog of Sirok is situated in the northern part of the country, in the eastern foothills of the Mátra Mts, at an elevation of $250 \mathrm{~m}$ (Figure 4). It covers a small area, of about $9,000 \mathrm{~m} 2$. No surficial watercourses feeding or draining the peatland are known. The basin is fringed by a woodland of hornbeam (Carpinus betulus) and oak (Quercus petraea). The following plant communities are present, moving from the margins towards the center: Salicetum cinereae, Salicetum cinereaeSphagnetum, Carici lasiocarpae-Sphagnetum. There is a small stand of reedbed on the eastern side of the peat bog. This peatland harbors the following peat moss taxa: Sphagnum palustre, S. subsecundum, S. magellanicum, $S$. recurvum s. l., S. fimbriatum, S. squarrosum, S. obtusum and $S$. angustifolium. The most common are those of Sphagnum recurvum s. l. and S. palustre [35,36].

Szurdoki [36] investigated the abiotic conditions of some of the most frequent Sphagnum, in five Hungarian mires, among others the Nyírjes-tó peat bog. Conductivity, $\mathrm{pH}$, height above water table, $\mathrm{Na}, \mathrm{K}, \mathrm{Ca}$ and $\mathrm{Mg}$ concentrations were detected. The investigated peat bogs were similar, but there were many significant differences between them in terms of analytical variables, and only weak differences within mires. On the basis of water table, $\mathrm{pH}$, and conductivity the investigated species can be separated. S. fallax and S. angustifolium do not differ from each other, which is not a surprise since they live together in mixed carpets in most investigated mires.

They mainly occur in wet and acidic locations with poor mineral content. S. palustre lives in the driest places and S. fimbriatum in wet and less acidic ones, which are characterized by the highest mineral content. According to Szurdoki [36] the most characteristic features of the Hungarian peat bogs are low $\mathrm{pH}$ (c. $\mathrm{pH} 4)$ and conductivity of $40-80 \mu \mathrm{S} / \mathrm{cm}$; however, the concetration of calcium proved to be relatively high $\left(10 \mathrm{mg} / \mathrm{dm}^{3}\right)$ within aEuropean context. The $\mathrm{pH}$ of the Nyírjes-tó surface peat layer fluctuated between 3.5 and 4.5 [35,36]. The concentration of nutrients and the water level of Nyírjes-tó is the lowest among the Hungarian peat bogs. The main water level is $17 \mathrm{~cm}$ from the peat surface, but in late summer it can be as low as $30 \mathrm{~cm}$ [36]. Penksza et al. [37] investigated the heavy metal accumulation in peat and in peat-forming mosses and vascular plants from the Nyírjes-tó. Unfortunately the stratigraphic resolution was insufficient and radiocarbon dating was lacking. Therefore the comparison with our paleoecological results is problematic. A detailed palynological work on the peatland was published by Gardner [17,18]. The comparison of terrestrial and wetland vegetation development is based on the results of Gardner [17,18].

First, confirm that you have the correct template for your paper size. This template has been tailored for output on the custom paper size $(21 \mathrm{~cm} \times 28.5 \mathrm{~cm})$.

\section{Methods}

The sampling of the $401 \mathrm{~cm}$ deep, undisturbed sedimentary sequences of the Nyírjes-tó Basin was carried out using a $5 \mathrm{~cm}$-diameter Russian-type corer [38]. Overlap- 
ping cores were extracted conforming to the general practice in Quaternary paleoenvironmental studies [39]. Coring was carried out in the central part of the bog, now occupied by the Carici lasiocarpaea-Sphagnetum community. Samples taken between the depths of 401 and 4 $\mathrm{cm}$ were subjected to plant macrofossil analyses. The Psimpoll program [40] was used for plotting the analytical results. The main lithostratigraphic features of the sedimentary sequence were determined and analyzed. For the description of the cores, the internationally accepted system and symbols of Troels-Smith, developed for unconsolidated sediments, was adopted [41]. Dating of the sequence was carried out by conventional radiocarbon dating at the radiocarbon dating facility in Gliwicze, Poland. Four bulk samples ( 6 - 10 g peat) of sediment were analyzed for radiocarbon ages. In order to allow comparison with other archeological data, the dates were calibrated using the CalPal-2007 online calibration programme, using the most up-to-date CalPal-2007 Hulu calibration data set [42]. The original dates $\left({ }^{14} \mathrm{C}\right)$ are indicated as BP, while the calibrated dates are indicated as cal BC/AD or cal BP. For a more accurate dating of the lower part of the core, additional radiocarbon measurements are under way. For the description of macrofossils a modified version of the QLCMA technique (semiquantitative quadrat and leaf-count macrofossil analysis technique) of Barber et al. [22] and [43] was used. To obtain concentrations for the macrofossil components, a known amount of marker grains ( $0.5 \mathrm{~g}$ poppy seeds, ca. 960 pieces) were added to the samples. In the diagrams the total number of seeds relates to $20 \mathrm{~cm}^{3}$ sediment, while other macrofossil components are expressed as concentrations (piece $\cdot \mathrm{cm}^{-3}$ ). Organic remains from peat and lacustrine sediments rich in organic matter can be divided into two major groups. Some remains can be identified with lower ranking taxa (specific peat components), while others cannot be identified using this approach (non-specific peat components).

The archaeobotanical material for anthracological analysis was obtained from samples of archaeological profiles and the deposits of the archaeological features [10]. The sampled objects were both short (e.g. hearth) and longterm deposits (e.g. midden, refuse pit, fills, well fills, ceramic filling). In obtaining and processing the samples we followed the guidelines of the German standards [44, 45] regarding sampling and flotation process. The samples were wet floated; afterwards charcoal fragments were selected and counted. The number of charcoal fragments varied according to the archaeological objects excavated from the level of a certain archaeological culture. During charcoal analysis pieces larger than $4 \mathrm{~mm}$ were the most useful, as smaller fragments are in most cases unidentifiable [46-48]. The microscopic identification of wood is possible by knowing the unique tissue map of the given genera or species. Cross-sectional, radial and tangential sections were prepared when analysing charcoals [49], created by breaking new surfaces by hand or with a scalpel. The charcoal pieces were placed in fine sand for ease of manipulation. The three directional sections were analysed using a petrographic microscope, at $50 \times$ and $100 \times$ objectives. The identification was carried out by reference to published specimens [50-52].

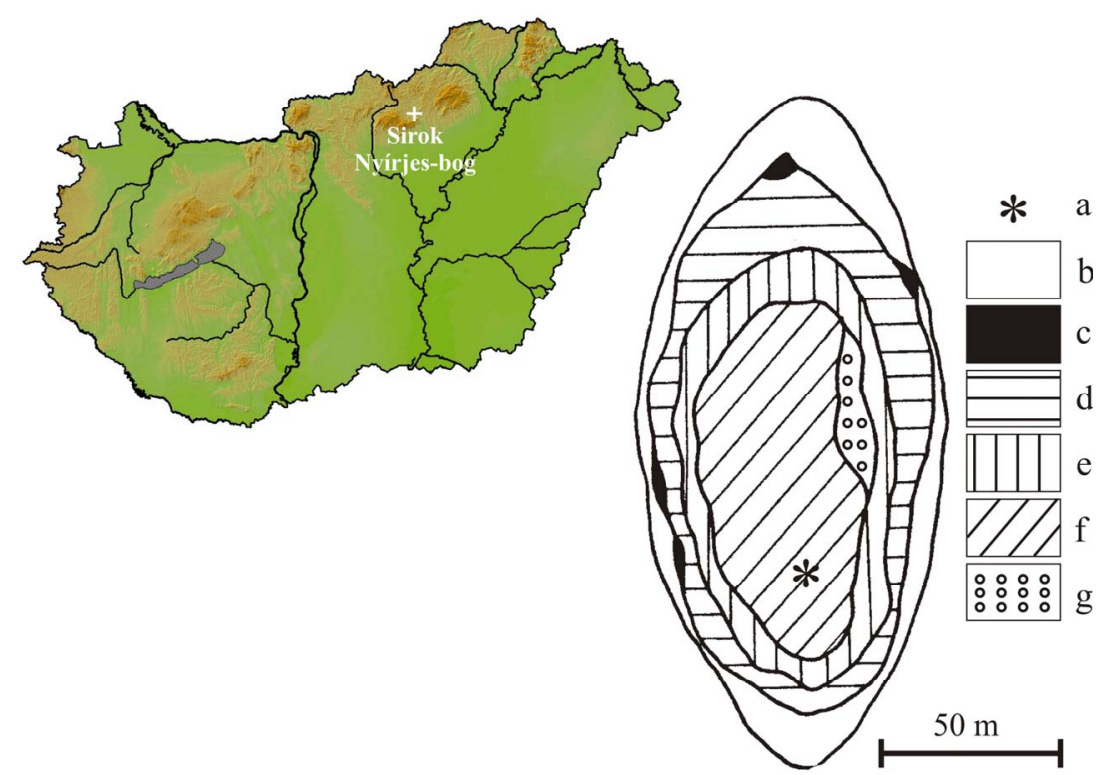

Figure 4. Location of the study site in Hungary and the coring point in the peat bog (a: coring point, b: marginal marsh, c: Lemno-Utricularietum, d: Salicetum cinereae, e: Salicetum cinereae with Sphagnum, f: Carici lasiocarpae-Sphagnetum, g: Saliceto-Sphagnetum, original map: [35]. 


\section{Results and Discussion}

\subsection{Chronology and Sediment Stratigraphy}

On the basis of the sedimentological features the core was divided into 12 units. In general mixed Sphagnum, reed and sedge peat was found down to a depth of 210 $\mathrm{cm}$. Between $210-300 \mathrm{~cm}$ mixed reed and sedge peat was encountered; between $300-340 \mathrm{~cm}$ occurred a brown moss peat with high wood content. Between $340-410$ $\mathrm{cm}$ dark gray, silty lacustrine sediments were found with wood and moss fragments. The detailed sediment de- scription is presented in Table $\mathbf{1}$.

The results of the radiocarbon measurements of the sequence described in this udy are shown in Table 2. The age-depth model was established by linear terpolation between the calibrated radiocarbon dates (Figure 5). Sedimentation rates are shown in Table 3. The bottom part of the investigated part of the core, between 195 - 315 $\mathrm{cm}$, is characterized by very low values $\left(0.25 \mathrm{~mm} \cdot \mathrm{yr}^{-1}\right)$; the dimentation rate increases gradually between 38 $195 \mathrm{~cm}$ from 0.25 to $1.16 \mathrm{~mm}^{-1}$, and attains the highest values in the top $38 \mathrm{~cm}$ of the core $\left(3.39 \mathrm{~mm} \cdot \mathrm{yr}^{-1}\right)$.

Table 1. Lithological description of the Nyírjes-tó sequence.

\begin{tabular}{|c|c|c|}
\hline Depth $(\mathrm{cm})$ & Troel-Smith system (1959) & Zone description \\
\hline $0-20$ & $\mathrm{~Tb}$ (Sphag.) $4 \mathrm{Th}+\mathrm{As}+\mathrm{Gs}+$ & Light brown recent Sphagnum-peat with silt. \\
\hline $20-60$ & $\mathrm{~Tb}$ (Sphag.)2Th2 & Light brown mixed Sphagnum-, reed and sedge peat \\
\hline $60-80$ & $\mathrm{~Tb}$ (Sphag.)4Dl+ & Dark brown Sphagnum peat. \\
\hline $80-120$ & Th2Tb2D1+ & Dark brown Sphagnum, reed, sedge peat with wood fragments. \\
\hline $120-160$ & $\mathrm{~Tb}$ (Sphag.)3Th1D1+ & Dark brown Sphagnum, reed, sedge peat with wood fragments. \\
\hline $160-185$ & Th3As1Tb(Sphag.)+D1+ & Dark brown reed, sedge peat with wood and Sphagnum moss fragments. \\
\hline $185-210$ & $\mathrm{~Tb}$ (Sphag.)4Th+Tl+ & Dark brown Sphagnum-peat, with reed, sedge and wood fragments. \\
\hline $210-285$ & Th2As1D11Tb(Sphag.)+ & Dark brown reed, sedge, peat with wood and Sphagnum moss fragments. \\
\hline $285-300$ & Th3As1D1+Tb+ & Dark brown sedge (Carex elata) peat with some wood and Sphagnum moss fragments. \\
\hline $300-340$ & Tb2As1T11Th+ & Dark brown brownmoss peat with many wood fragments. \\
\hline $340-360$ & As2Ag2Gs + & Dark grey clayey silt (lake) sediment layer. \\
\hline $360-410$ & As3Sh1Gs+Tb+Dg+ & Dark grey clayey silt (lake) sediment layer with moss and wood fragments. \\
\hline
\end{tabular}

Table 2. Radioocarbon data from the Nyírjes-lake.

\begin{tabular}{|c|c|c|c|c|}
\hline Sample No. & Depth $(\mathrm{cm})$ & Sample type & ${ }^{14} \mathrm{C}$ age (uncal BP) & cal $\mathrm{AD} / \mathrm{AD}(2 \sigma)$ \\
\hline GdA-565 & $37-38$ & peat & $55 \pm 30$ & $1889 \pm 83$ \\
\hline GdA-566 & $99-100$ & peat & $560 \pm 30$ & $1364 \pm 41$ \\
\hline GdA-567 & $195-196$ & peat & $1680 \pm 30$ & $353 \pm 41$ \\
\hline GdA-568 & $315-316$ & peat & $5640 \pm 40$ & $4465 \pm 52$ \\
\hline
\end{tabular}

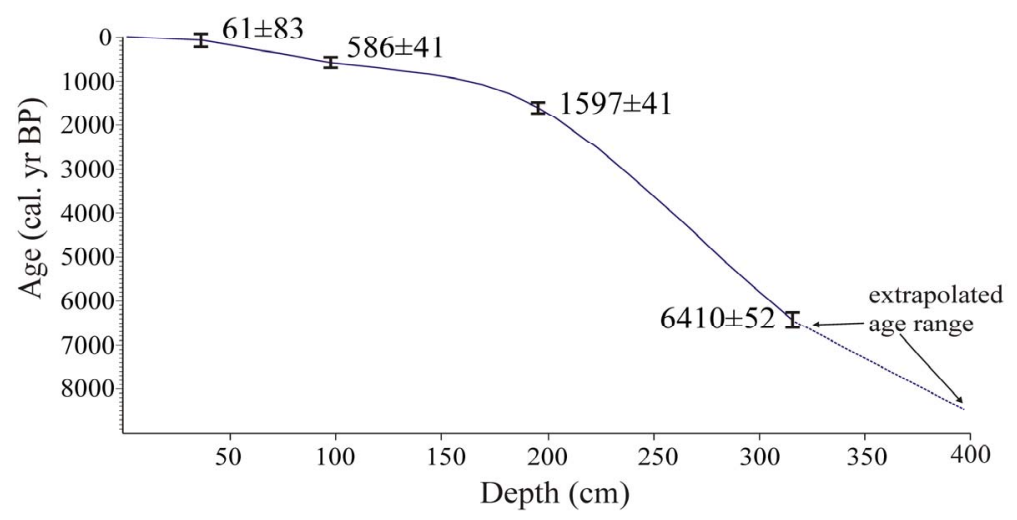

Figure 5. Calibrated radiocarbon age ranges (1) and suggested age-depth curve for core SI (Sirok Nyírjes-tó). All dates were converted into calendar years BP using the CalPal-2007 online calibration program [42]. 
Table 3. Sediment accumulation rates from the Nyírjes-tó sequence. The age of the upper point concerned AD 2007.

\begin{tabular}{cc}
\hline Depth ranges & Sediment accumulation rates (mm/year) \\
\hline $0-38$ & 3.39 \\
$38-99$ & 1.16 \\
$99-195$ & 0.95 \\
$195-315$ & 0.25 \\
\hline
\end{tabular}

These sedimentation rates are related to the sediment types accumulated in the basin. Above $210 \mathrm{~cm}$ Sphagnum and reed peat can be found with high organic content. Subsamples for macrofossil analysis were taken at 4 $\mathrm{cm}$ intervals, which correspond to $40-50 \mathrm{yr}$ resolution in the last 2000 years and $130-150 \mathrm{yr}$ resolution before 2000 yrs BP. Nevertheless the resolution of radiocarbon dating in the lower 2 meters is unsatisfactory, so a more accurate stratigraphic resolution requires further radiocarbon measurements. Terrestrial and wetland vegetation development Figure 3 displays the tissue, moss, animal and seed remains extracted from the investigated sequence. Table 4 presents the most important characteristics of the local macrofossil zones. On the basis of the results the following evolutionary history of the peatland and the sorrounding watershed can be drawn.

\subsection{Terrestrial and Wetland Vegetation Development}

The first emergence of aquatic conditions in the depression can be dated to $9500 \mathrm{cal}$. yr BP, resulting in the emergence of a relatively deep, oligotrophic lake with scant aquatic vegetation. As shown by the palynological

Table 4. Discussion of the macrofossil assemblages of the Nyírjes-lake sequence.

\begin{tabular}{|c|c|c|c|}
\hline Depth $(\mathrm{cm})$ & $\begin{array}{c}\text { Age } \\
\text { (cal BP years) }\end{array}$ & Local zones & Zone description \\
\hline $6-32$ & $61-$ & SIM-9 & $\begin{array}{l}\text { Degrading oligotrophic peat bog conditions. Beside the high amount of Sphagnum recurvum, the } \\
\text { leaves of } S . \text { squarrosum and palustre indicate gradual eutrofication. Clay particles and mollusc } \\
\text { shells indicate soil erosion in the catchment. Carex lasiocarpa, Calamagrostis canescents were } \\
\text { the most common vascular plants. }\end{array}$ \\
\hline $32-71$ & $380-61$ & SIM-8 & $\begin{array}{l}\text { Dry oligotrophic peat bog conditions, Sphagnum concentrations decrease, Carex elata and } \\
\text { Phragmites concentrations rise. Juncus indicates degradation. }\end{array}$ \\
\hline $71-88$ & $500-380$ & SIM-7 & $\begin{array}{l}\text { Wet oligotrophic peat bog conditions. Beside the dominant } S \text {. recurvum, S. cuspidatum show a } \\
\text { remarkable peak. Peat bog vegetation dominated by Calamagrostis canescens, Carex lasiocarpa, } \\
\text { C. canescens, C. limosa and Eriophorum vaginatum. Occurrence of Sphagnum cuspidatum and } \\
\text { Carex limosa indicates conditions wetter than now. }\end{array}$ \\
\hline $88-188$ & $1500-500$ & SIM-6 & $\begin{array}{l}\text { Macrofossil concentrations show remarkable fluctuations in this zone. High concentrations of } \\
\text { reed and peat moss remains alternate from time to time. The first Sphagnum peaks dominated } \\
\text { by S. obtusum, S. subsecundum, S. magellanicum. }\end{array}$ \\
\hline $188-213$ & $2300-1500$ & SIM-5 & $\begin{array}{l}\text { Oligotrophic peat bog conditions with high concentrations of Sphagnum leaves, Carex lasiocarpa } \\
\text { and C. rostrata rhizomes and Betula remains. }\end{array}$ \\
\hline $213-284$ & $5200-2300$ & SIM-4 & $\begin{array}{l}\text { Amount of Quercus remains decreased caused by rising water level. Pond weeds, weeds living } \\
\text { on wet mud and planctonic invertebrates were characteristic of this zone. Lakeshore vegetation } \\
\text { dominated by Carex elata, C. paniculata, and Glyceria maxima. Later Phragmites, Carex } \\
\text { rostrata and Typha angustifolia become dominant. A short peat bog expansion was detected } \\
\text { at } 3900 \mathrm{yr} \text { BP, with Sphagnum and Eriophorum. }\end{array}$ \\
\hline $284-299$ & $5800-5200$ & SIM-3 & $\begin{array}{l}\text { High macrofossil concentrations. Shallow mesotrophic mire conditions with higher water levels. } \\
\text { Hummock-holow structure with Carex elata and Menyanthes trifoliata. }\end{array}$ \\
\hline $299-343$ & $7500-5800$ & SIM-2 & $\begin{array}{l}\text { High macrofossil concentrations. Shallow mesotrophic mire conditions, with fluctuating water } \\
\text { level and abundant brown moss carpet. Remains of Quercus were quite frequent in this zone. } \\
\text { The rhizomes of Phragmites, Carex elata, C. paniculata, Glyceria maxima and the moss } \\
\text { Drepanocladus aduncus dominated the macrofossil record. A short peat bog expansion was } \\
\text { detected at ca. } 6800 \text { cal. yr. BP, when Sphagna, Carex rostrata, C. pseudocyperus, } \\
\text { C. lasiocarpa, Thelypteris palustris and Meesia longiseta spread in the basin. }\end{array}$ \\
\hline $343-401$ & $9500-7500$ & SIM-1 & $\begin{array}{l}\text { Low macrosossil concentrations. Deep oligotrophic lake conditions, with a short peatland } \\
\text { expansion at ca. } 8200 \text { cal. yr BP. Lakeshore vegetation was dominated by Carex elata, } \\
\text { Phragmites, Sphagnum magellanicum and S. recurvum s.l. }\end{array}$ \\
\hline
\end{tabular}


study of Gardner $[7,8]$ the lake basin was fringed by an open parkland-type woodland with predominance of Picea, Quercus and Corylus untill about 8950 cal. yr BP. This was transformed into a woodland dominated by Tilia until 8300 cal. yr BP, which was then finally transformed into a deciduous woodland dominated by Quercus, Tilia and Ulmus until 6900 cal. yr BP, with substantial stands of Corylus. Despite the clearly observable transformation of the surrounding vegetation, water levels remained relatively stable in the basin, apart from minor fluctuations, until $7500 \mathrm{cal}$. yr BP. A drop in water level (increasing concentrations of UOM, UBF and wood) and peat initiation took place almost 1000 years after the development of a closed, deciduous woodland. Therefore there is no direct link between the transformation of the vegetation of the peatland itself and the surrounding terrestrial areas. There is a gradual decrease in water levels from 7500 cal. yr BP, reaching an all time minimum at 6400 cal. yr BP. Open water areas almost completely disappeared, giving way to the expansion of oak shoots in the major part of the basin. The deepest areas turned into an eutrophic marshland and as such we must assume a gradual decrease in the water level from $5800 \mathrm{cal}$. yr $\mathrm{BP}$, yielding a tussock vegetation. During this period the peatland was fringed by a woodland of Corylus, Quercus and Carpinus betulus $[7,8]$.

There is another rise in the water level from $5200 \mathrm{cal}$. yr BP, resulting in the expansion of the peatland. This was accompanied by the appearance of floating mats in the expanding shallow eutrophic pond harboring peat mosses in larger amounts. There is a rapid spread of Carpinus betulus in the adjacent closed oak woodlands at that time [7,8]. Peak distribution of Fagus sylvatica and Carpinus betulus was found between 3700 and $1750 \mathrm{cal}$. yr BP [7]. A similar expansion of Sphagna is indicated by the macrofossil diagram after $3900 \mathrm{cal}$. yr BP in the basin, with the first appearance of real acidophyllic Sphagnum peatlands dated between 2300 and 1500 cal. yr BP. From 1500 cal. yr BP there is an alternating succession of Sphagnum peatlands with reed and sedge peatland horizons, reflecting the alternations of cooler (Sphagnum peaks) and warmer (Phragmites peaks) periods up to the present day. Optimal Sphagnum peatland conditions were inferred at 500 cal. yr BP (AD 1550), with such taxa as Sphagnum cuspidatum. As shown by the results of Gardner [7] there is an increase in human influence in the area from $1750 \mathrm{cal}$. yr BP as seen in the drop in the amount of Fagus and Carpinus, accompanied by an advent of Quercus.

The past century was also a period of Sphagnum peatland expansion. The presence of clayey horizons embedding mollusc shells and carbonate concretions intercalating the peat horizons are clear signs of soil erosion in the adjacent areas, triggered by deforestation of the nearby slopes. As an outcome of these activities the amount of rainfall reaching the surface substantially increased, resulting in an increase of the water level in the bed of the peatland and triggering the expansion of Sphagna. A similar phenomenon was described from several other European sites [53-55].

\subsection{Changes in Bog Surface Wetness}

The climate reconstrucion is based on the plant macrofossil investigations of the peat sequence. Figure 6 presents the changes of the main macrofossil groups on the cal. BP timescale. The spread of shrubs, trees and sedges at the expense of Sphagna due to the drainage or the present-day climate change is a well-known phenomenon of the Hungarian peat bogs, which are under strong continental climatic effects [56,57]. It is an obvious assumption that the detected shifts in Sphagna percentages were triggered by climatic deteriorations (colder or more humid climate). Such climate deteriorations can be noticed at $8200,6800,3800,2150,1750,1300,1000,850,500$ and $200 \mathrm{cal}$. yr BP.

During these wet shifts different Sphagnum taxa become dominant in the basin, producing an unusual assemblage. According to the ecological investigations of Szurdoki [36] the niche breadth of the different Sphagnum species in the Hungarian peat bogs was wide, with high overlap. Szurdoki [36] argues that certain Sphagnum species utilize the different ecological resources similarly; therefore the competition between the different Sphagnum species is minimal. It is concluded that the strongly fluctuating environment caused the vanishing and re-establishment of Sphagna in the Hungarian peat bogs; therefore competition shortly after appearance determines the abundances. These frequently changing habitats produce strange species compositions.

The period between 7500 and 5200 cal. yr BP can be labeled as the driest part of the bog surface wetness history. The concentration of monocot remains is very low $(<5 \%)$; Sphagna remains are completely absent. In contrast UOM and tree remains (wood, ULF and budscales) show high peaks ( $>60 \%$ and $>20 \%$ ). Open water almost completely disappeared from the basin, and an oak forest occupied most of it.

\subsection{Paleoclimatic Reconstruction Based on Macrobotanical Remains}

Investigations of the Sirok Nyírjes-lake peat bog provide an almost full Holocene record of vegetation development affected by climatic changes. The emergence of an oligotrophic lake in the area was dated to $9500 \mathrm{cal}$. yr BP, with deeper lake water conditions. Changes in the surfi- 
cial moisture gradient of peatlands in the Carpathian Basin and those of lake level fluctuations are rather contradictory for this period.

High lake-level phases are known at 8500 cal. yr BP for different lakes and bog sin Hungary [58,59]. The inferred water levels of Lake Sf Ana in Romania show a highstand at 9500 cal. yr BP, with the emergence of a lowstand at 9000 cal. yr BP [60,61]. Conversely, studies implemented at various sites of the Great Hungarian Plain reconstructed a long-lasting dry and warm period till about 4400 cal. yr BP $[43,59,62]$. There seem to be substantial regional differences in the Early and Middle Holocene climate of the Carpathian Basin. Decreasing water levels inferred at $7500 \mathrm{cal}$. yr BP culminated in the driest phase of the peatland, recorded at 6400 cal. yr BP. This period is the time of Holocene climatic optimum, when there is a substantial retreat of the Swiss Alp glaciers between 7450 and 6650 cal. yr BP and between 6200 and 5650 cal. yr BP [63]. Conversely, there is an inferred increase in the water level of Lake Szent Anna in Romania from 7500 cal. yr BP onward, interrupted by a short decrease between 5500 and 5300 cal. yr BP [60, 61]. According to Cheddadi et al. [64] and Davis et al. [65] the traditionally postulated Holocene climatic optimum is identifiable only in Northern Europe. At this time southern Europe was characterized by colder conditions, with Central Europe occupying a transitionary phase. This assumption is refuted by the findings of paleoecological studies made on lake and marshland basins in the Carpathian Basin.

Nevertheless the definition and limitation of the Holocene climatic optimum is ambiguous and depends on the geographic position and the type of applied methodology. Paleoclimatological reconstructions based on pollen analytical results from Hungary argue that the Holocene climatic optimum can be detected between 7000 and 8000 cal. yr BP [66], or somewhat earlier between 7000 an 8100 cal. yr BP [67].
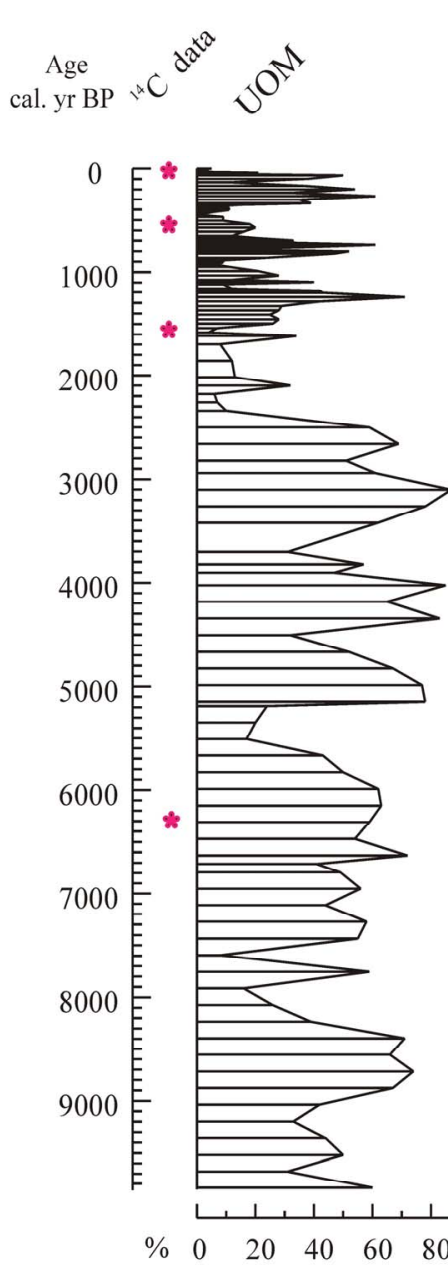
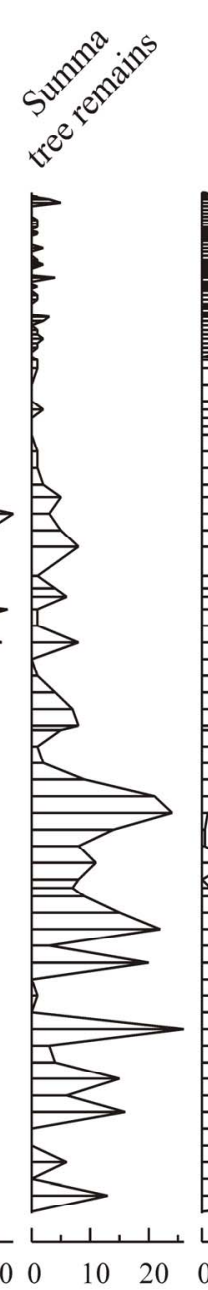
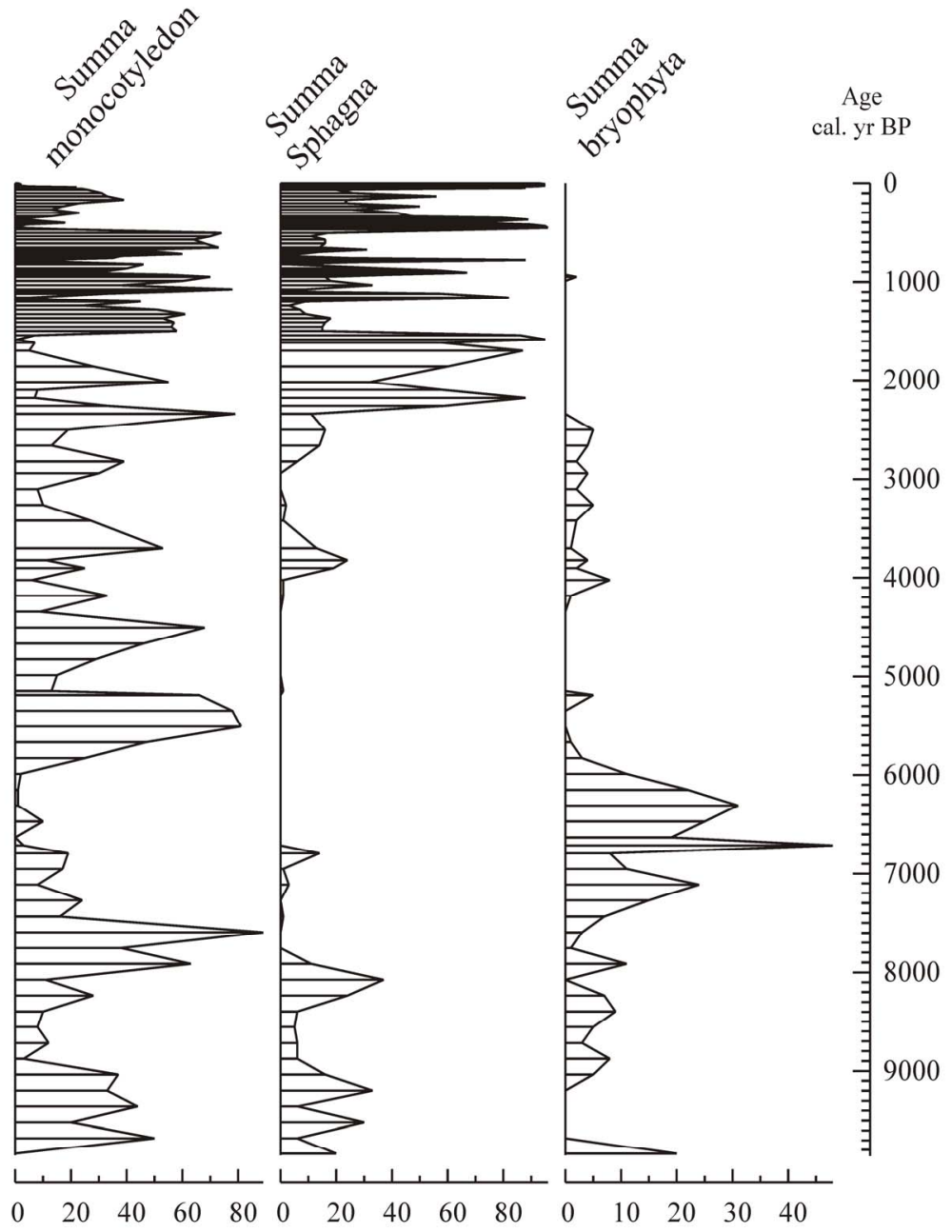

Figrue 6. Selected macrofossil diagram of the Sirok Nyírjes-lake peat bog. UOM = Unidentified organic material. 
Following the climatic optimum there are two periods when a substantial increase in the surface moisture gradient was observable in the referred study site: at 5800 and $5400 \mathrm{cal}$ yr BP. This change is congruent with the pattern observable in other lacustrine and marshland basins of the Carpathian Basin, also displaying an increase in the water level. There is a sudden increase in the water level of the Lake Szent Anna from 5500 cal. yr BP [60, 61] and Lake Balaton from 5200 cal. yr BP [58]. A somewhat delayed, similar pattern is observable in the peatlands of the GHP starting at 4400 cal. yr BP [43]. This period between 5600 and $5300 \mathrm{cal}$. BP is referred to as the Middle Holocene Climatic Transition, characterized by a sudden deterioration of the previously warm conditions as a result of the collective transformation of orbital forces, solar activity and ocean currents $[68,69]$.

Three short-lived peat formation events were identified at 8200, 6800 and $3800 \mathrm{cal}$. yr BP, reflecting cooler conditions. Paleoecological records available from the Carpathian Basin have yielded no information of climate change for this period so far. There is a marked cooling related to a global cooling event lasting for merely 200 years, known as the "8.2 ky event" [70-73]. At $6000 \mathrm{cal}$. BP a high lake-level phase of Swiss lakes [74,75] and changes in the moisture gradient of some British peatlands [15] point to the emergence of cooler conditions. Similarly at 3500 cal. yr BP, the higher lake phase of Swiss lakes [74,76], the expansion of Alpine glaciers [77], and an increase in the moisture gradient of numerous Western European peatlands marks a cooling of the climate $[15,17]$. These Sphagnum shifts around 8200, 6800 and 3800 cal. yr BP at Nyírjes-lake coincide with the short-term climatic oscillations presented by Feurdean et al. [78] using pollen-based climate reconstruction methods.

An increase in the amount of Sphagna from $2800 \mathrm{cal}$. yr BP in the Nyírjes-lake peat bog also marks a cooling of the climate and the accompanying rise in rainfall. This deterioration of the climate, starting at $3500 \mathrm{cal} \mathrm{yr} \mathrm{BP,}$ culminates here in the Carpathian Basin, as was shown by numerous records. Water levels were the highest in the Lake Szent Anna in Romania at this time, and there is information concerning the development of layering in the water body for this period $[60,61]$. Along with this data, information from studies of testacea and humic content of peatlands in the Eastern Carpathians show an increase in the moisture gradient [79]. The resuming peat formation in certain Hungarian peatlands marks the cooling of the climate here [80]. On the whole these data suggest increasing moisture availability in the Carpathians and the adjoining Carpathian Basin from ca. $3400 \mathrm{yr}$ BP, with maximum moisture availability around 2700 2800 years BP.
The first real acidophyllic Sphagnum peatland developed at Sirok between 2300 and 1500 cal. yr BP. From here on we have a record of alternating phases of Sphagnum peatlands and sedge/reed peatlands. As displayed by the record of vegetation changes, the catchment of the referred peatland was highly prone to climatic fluctuations. Certain periods are characterized by a rapid expansion of Sphagna, and others by the expansion of sedge and reed. A sudden expansion of Sphagna was recorded at least 10 times. Figure 6 displays a comparison of changes inferred from the Nyírjes-lake peat bog with cooler periods determined by Barber et al. [20] and Mauquoy and Barber [21], emphasizing changes for the last 3000 years. The Sphagnum peaks perfectly match the more humid periods identified in the British Isles at 2150, $1750,1300,1000,850,500$ and 200 cal. yr BP $[17,20$, 21], indicating some collective global force as the cause for these changes. Barber and Charman [17] identified centennial-scale climatic fluctuations in different parts of Western Europe. The length of these cycles was variable, spanning $210,600,800$ or 1100 years in different peatlands. No such cycles have been identified in Central Europe so far.

The bog-surface wetness investigations with testate amoebae of Schnitchen et al. [81] from the eastern Carpathians presented a period of greater variability in hydrological conditions after 3000 cal. yr BP. Significant shifts to wet conditions occurred, peaking at 2725, 2240, $1665,1170,590$ and 385 cal. yr BP. These wet shifts more or less coincide with the wet periods of the Nyírjeslake (Figure 7). It is worth comparing paleoecological data of the site of the present study over the last 3000 years with those of written historical records. One major climatic crisis in the Carpathian Basin is connected to the Migration Age. Written records blame famines and wars triggered by the extreme droughts during this period [82, 83]. Little environmental historical data for this time has been available so far. As shown by the Sphagnum curve of our referred study site, this period was indeed characterized by dry conditions (Figure 7) troughts during this period $[82,83]$. Little environmental historical data for this time has been available so far. As shown by the Sphagnum curve of our referred study site, this period was indeed characterized by dry conditions (Figure 7).

Another major historical crisis was the appearance of Mongol tribes in the area n 1241 - 1242. Certain sources blame this on severely cold weather, while others $1 \mathrm{k}$ about the extreme droughts $[84,85]$. As shown by our paleoecological data for the Nyíres-lake peat bog, Hungary was characterized by extremely warm conditions during this period, resulting in an almost complete dessication of the Sphagnum peatland. The Sphagnum curve of the Nyíres-lake enables us to identify the period of the 


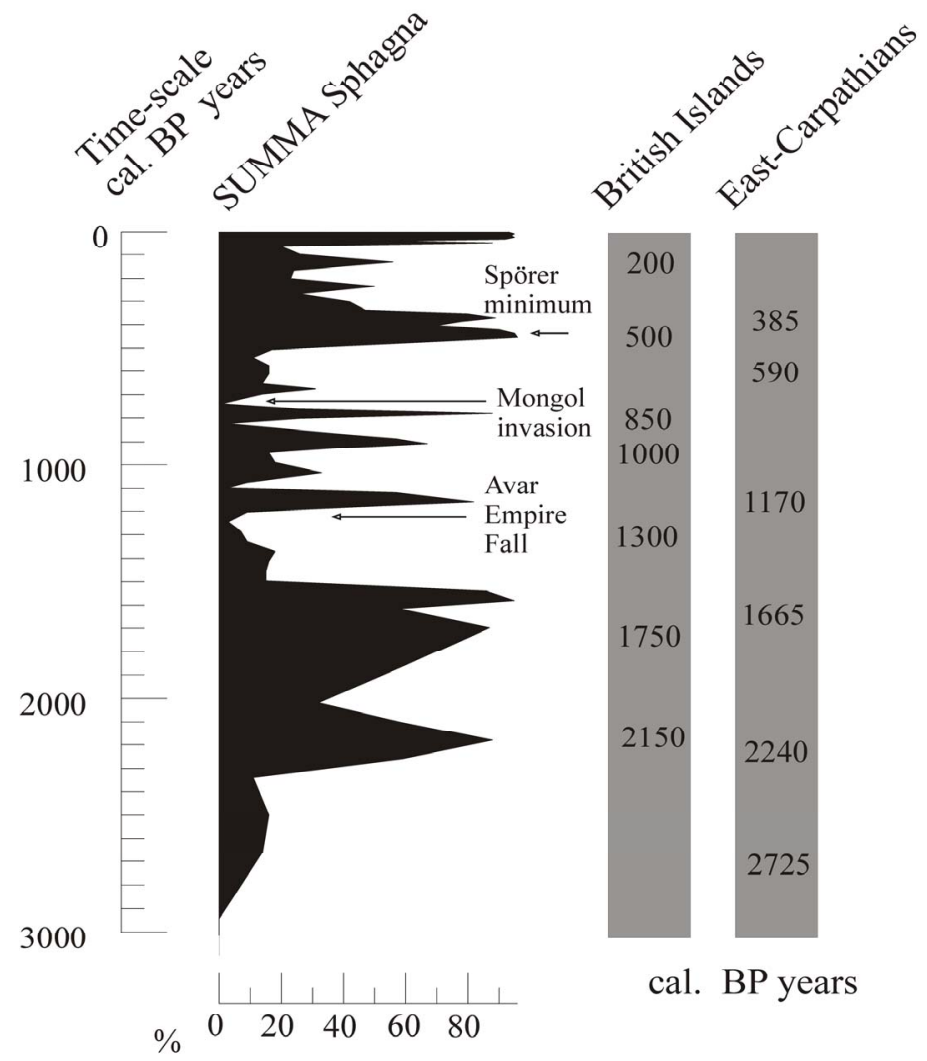

Figure 7. Comparison of bog surface wetness changes of the Sirok Nyírjes-lake and some British [20,21] and Romanian [79] peat bogs in the last 3000 years. The arrows show some historical events.

Little Ice Age (LIA), dated between the middle part of the 16th century till the middle part of the 19th century [86-88]. The environmental record for the Nyírjes-lake peat bog fits with these events as well. The most diverse Sphagnum taxa, including the hygrophilous Sphagnum cuspidatum, was present here at the end of the 16th century. Sphagnum cuspidatum does not currently occur in the Nyírjes-lake. Western European peatlands were similarly prone to the fluctuating climate of the LIA [89]. Wetter conditions were identified from the beginning of the 16th and middle part of the 17th centuries. LIA climate deterioration can be detected in several proxy-climate records in the Carpathian Basin as well. Based on the Eastern Carpathian tree-ring width chronology of Popa and Kern [90] the fingerprint of the LIA is visible between AD 1370 and 1630, followed by lagged cold decades in AD 1820 and 1840. Tree-ring data between AD 1460 and 1510 strongly correlated with Alpine reconstructions. This suggests strong regional forcing predominant over the eastern Carpathians and the Alps, producing a uniquely European signal. The high-resolution stable isotope and trace element records from a stalagmite from Hungary showed that during the LIA, the coldest years (longer or colder winters) occurred from around $\mathrm{AD} 1550$ to ca. 1700 [59].

\subsection{Anthracological Analysis}

A total of 138 samples, containing 6062 identified pieces of charcoal derive from the rescue excavations of the MO motorway [10]. The age of the samples was obtained according to the archaeological findings. Figure 8 represents the relative frequencies of the identified taxa obtained from the charcoal fragment counts of the most frequent taxa and the sum of Spagnum chronologically.

During the Late Iron Age only two genera occurred, $87.3 \%$ of the charred wood material is Quercus, while the remaining $12.7 \%$ is Fraxinus (Figure 8). During the Sarmatian period the anthracological material is more diverse, unlike in the previous period. $85.4 \%$ of the charred wood remains is Quercus, $12.2 \%$ is Ulmus, $1.4 \%$ is Fraxinus, $0.8 \%$ is Fagus and $0.2 \%$ is Carpinus. The diversity of the anthracological material may indicate that because of the decrease in the number of the main forest taxon (e.g. Quercus) other species have also been used for firewood as well as Quercus, although the number of Quercus fragments in the charred wood assemblage is still the highest. For the enlargement of ploughed land areas the felled trees may have been used for cooking, fires and making tools.

During the Migration period only a few pieces of 
Quercus and Ulmus charcoals were found. The anthracological material of the Middle ages indicate Quercus and Carpinus presence with values of $74 \%$ and $26 \%$.

\section{Conclusions}

If we would like to understand the background of the natural variability of the prospective climatic change, it is important to study the climate of the past. For this reason and the understand the changeability of the Holocene climate, it is significantly important to study and analyze peatbogs. As a matter of fact, by the analysis of plant macrofossils it is possible to detect the change of the surface wetness of bogs. In this way, the proxy data give information about the temperature of the different vegetation periods of different periods of time.

According to Blaauw et al. [91] there is a strong relationship between the moisture gradient of peatlands and solar activity reflected in the correlation of the former parameter with a proxy for $\delta^{14} \mathrm{C}$. One may properly ask what component of the climate controls the moisture gradient of peatlands via fluctuating solar activities? Surficial wetness is controlled by a complex interplay of precipitation and evapotranspiration of the plants, seen in such parameters as annual average rainfall and evaporation and influenced by the temperatures of the growth season. There are no surficial water courses feeding the Nyírjes-lake peat bog, so runoff must have been influential only during the past 100 years based on the hydrology of the peatland.

As was shown in Western Europe the moisture gradient of peatlands for the past 3000 years was primarily determined by fluctuations in the temperature of the vegetation season, rather than the amount of rainfall [16, 17,22,92-94]. According to Charman [95], in the Atlantic part of Europe summer precipitation and summer temperatures control the moisture gradient of peatlands. The pollen-based climate reconstructions from the eastern Carpathians [78] suggest that summer temperatures between 11200 and $8300 \mathrm{cal}$. yr BP were similar to those of the present. Between 8000 and 2400 cal. yr BP summer temperatures were higher than now. Pollen-based climate reconstructions indicated that summer temperatures became cooler in the last 2400 years. It seems that these general trends of summer temperatures determined the surface wetness history of the Nyírjes-lake peat bog. The relationships to other climatic parameters (e.g. annual precipitation, annual and winter temperature) investigated by Feurdean et al. [78] are conflicting. Unfortunately, macrofossil studies are not capable to accurately predict former temperatures or precipitation rates. Only the major trajectories of climate changes can be identified.

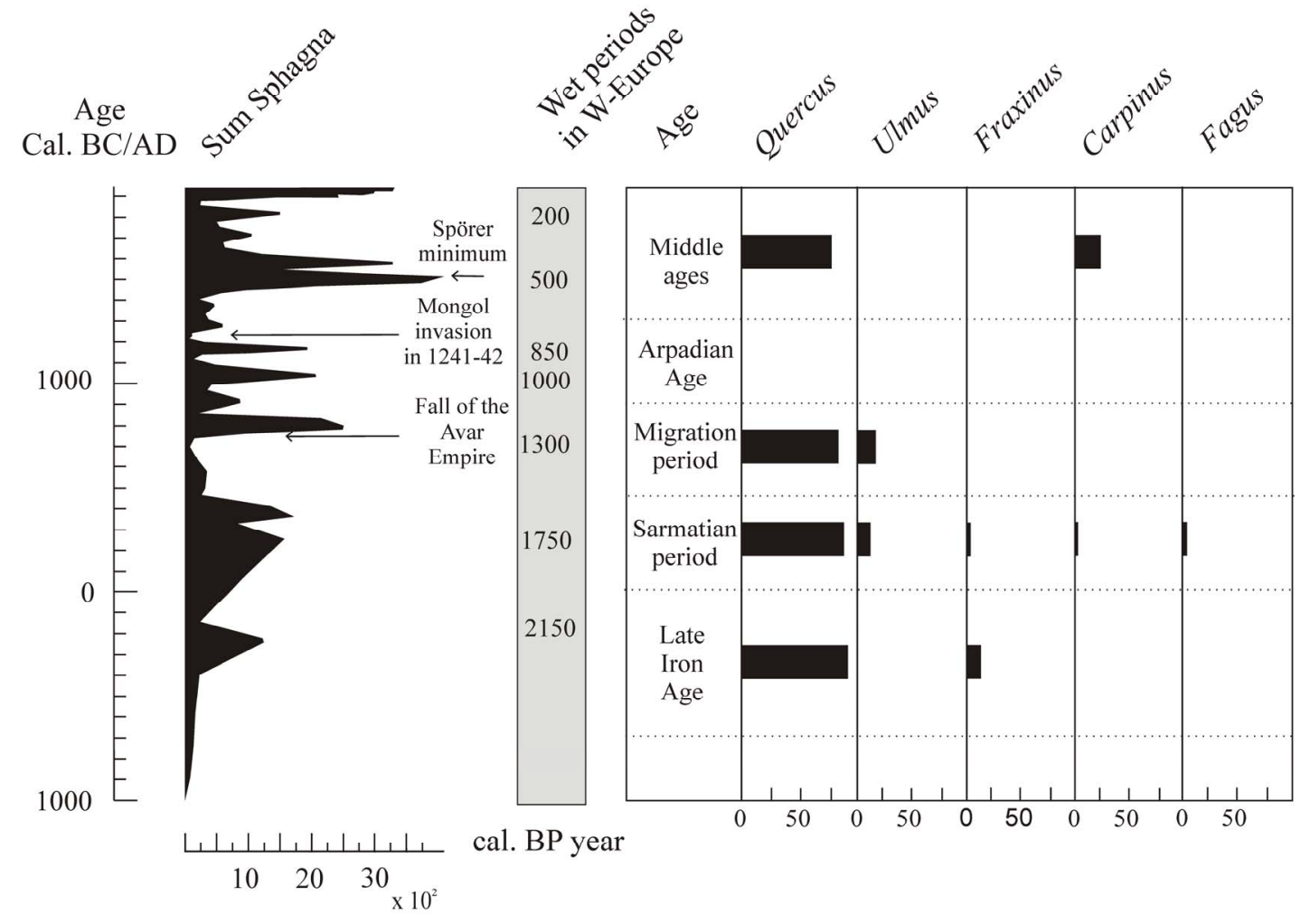

Figure 8. Bog surface wetness changes and relative frequencies of the most frequent taxa obtained from charcoal fragment counts. 
The modern distribution of Sphagnum peatlands in Hungary enables us to provide a rough estimate. Sphagnum peatlands appear in areas characterized by a precipitation of $600 \mathrm{~mm}$ per annum. Below this threshold one comes across only sporadic occurrences, while there are no Sphagna known below the lower limit of $550 \mathrm{~mm}$. Based on the results for the Nyírjes-lake peat bog conditions in the lower hilly areas during the drier periods of the past 3000 years may be inferred to have been similar to those of the central parts of the GHP. The complete disappearance of Sphagna from the area must be linked to a steady drop in rainfall, resulting in at least $50 \mathrm{~mm}$ deficit in the local water balance. This could have been achieved by an increased evapotranspiration as a result of elevated temperatures of the summer growth season. This deficit value must have exceeded even $100 \mathrm{~mm}$ during the Middle Holocene Transition.

These changes are supported by the studies of Zoltán Szelepcsényi $[11,12]$. In as much as the increase of the "cool temperate subhumid forest-steppe", life zone's area was successful in visualizing in the centre of Carpathian Basin applying the modified Holdridge life zone system during the last century. Thus we can observe the regional effect of the global warming (Figure 9). This progression's influence was detected in the change of the surface wetness of the Nyírjes bog. The surface wetness decrease
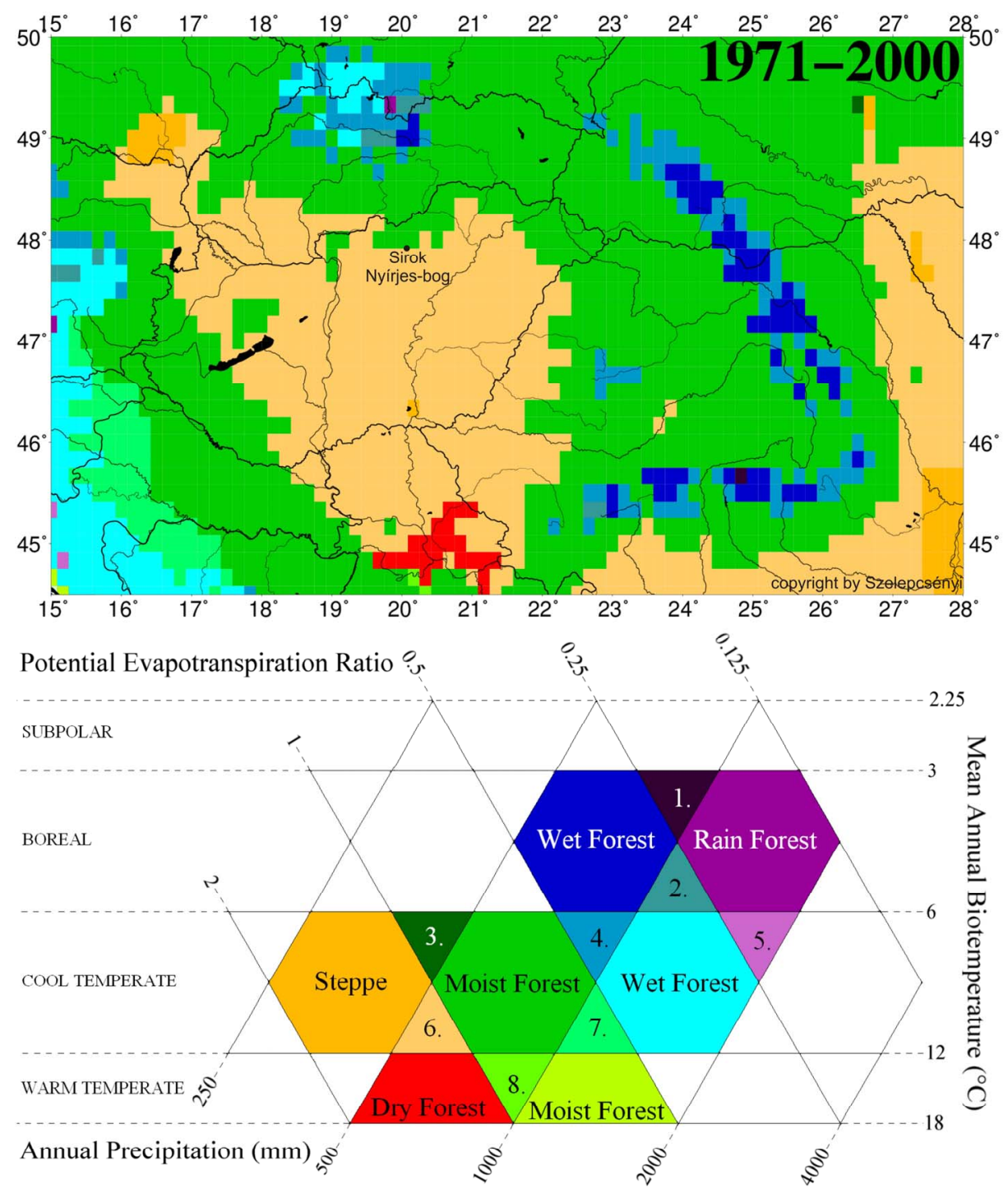

Figure 9. The spatial pattern of life zones at the end of 20th century (1971-2000) in Carpathian Basin for the modified Holdridge life zone classification [33] for the database CRU TS 1.2 [34]: 1) Boreal superhumid wet-rain forest; 2) Boreal perhumid wet-rain forest; 3) Cool temperate humid forest-steppe; 4) Cool temperate perhumid moist-wet forest; 5) Cool temperate superhumid wet-rain forest; 6) Cool temperate subhumid forest-steppe; 7) Cool temperate humid moist-wet forest; 8) Warm temperate humid dry-moist forest. 
in long term and in 30 - 50 years the amount of Sphagnum species decline. The development of Sphagna peat decline, the amount of reed and sedge decrease and reedsedge peat formed in Nyírjes-bog at Sirok. Parallel to this an open forest and forest steppe developed surrounding the bog.

These changes had a major effect on the human populations living in the basin during the last 3000 years. Almost in every warmer and drier climatic phase the forest steppe vegetation expanded and stock-breading populations (Scythian, Sarmatian, Avarian, Pecseng, Kun) became significant in the study area. The use of different types of wood was very low and homogenous, only a few species were used on the basis of the anthracological analysis of samples derive from archaeological sites [10].

On the basis of palaeoecological and environment historical research until now, the recent climatic change and warming up [4] would cause similar changes in the ecosystem of the Carpathian Basin as the previous warming up phases. The forest steppe vegetation would expand from the recent $100,000 \mathrm{~km}^{2}$ to $130,000-150,000 \mathrm{~km}^{2}$ parallel to this the ratio of the forested areas decrease on the foot of Carpathians the forests will open up and forest steppe vegetation will develop. The drought and temperature sensitive species such as Fagus could survive these conditions on the north slopes of hills and in deep valleys, populations living on plains or lowlands will dry out [5]. Drought resistive wood species, such as oaks will come into prominence but their stands will be loose structured. Parallel to these changes the agriculture and forestry of these areas will transform. The importance of forestry might decrease while animal husbandry increases - populations and agricultural communities living in the Carpathian Basin responded very similar to climatic changes during the last 3000 years.

\section{REFERENCES}

[1] S. Ødum, "Actual and Potential Tree Line in the North Atlantic Region, Especially in Greenland and the Faroes," Holarctic Ecology, Vol. 2, No. 4, 1979, pp. 222-227.

[2] R. W. Myster, "Introduction," In: R. W. Myster, Ed., PostAgricultural Succession in the Neotropics, Springer Press, New York, 2007, pp. 3-21.

[3] P. Sümegi, G. Persaits and S. Gulyás, "Woodland-Grassland Ecotonal Shifts in Environmental Mosaics: Lessons Learnt from the Environmental History of the Carpathian Basin (Central Europe) during the Holocene and the Last Ice Age Based on Investigation of Paleobotanical and Mollusk Remains," In: R. W. Myster, Ed., Ecotones between Forest and Grassland, Springer Press, New York. 2012, pp. 17-57. doi:10.1007/978-1-4614-3797-0_2

[4] J. Bartholy, I. Matyasovszky and T. Weidinger, "Regional Climate Change Results in Hungary: A Stochastic Downscaling Method," Idöjárás, Vol. 105, No. 1, 2001, pp. 1-
19.

[5] E. Führer and C. Mátyás, "A Klímaváltozás Hatása a Hazai Erdők Szénmegkötő Képességére és Stabilitására," Magyar Tudomány, Vol. 166, No. 7, 2005, pp. 837-841.

[6] P. Sümegi, "Loess and Upper Paleolithic environment in Hungary,” Aurea Kiadó, Nagykovácsi, 2005.

[7] A. R. Gardner, "Neolithic to Copper Age Woodland Impacts in Northeast Hungary? Evidence from the Pollen and Sediment Chemistry Records," The Holocene, Vol. 12, No. 5, 2002, pp. 521-553. doi:10.1191/0959683602hl561rp

[8] A. Gardner, "Natural Environmental or Human Impact? A Palaeoecological Study of Two Contrasting Sites in North-Eastern Hungary," In: E.-J. Gál and P. I. Sümegi, Eds., Environmental Archaeology in North-Eastern Hungary, Varia Archaeologica Hungarica Sorozat, XIX. Kötet, MTA Régészeti Intézet, Budapest, 2005, pp. 87106.

[9] G. Jakab and P. Sümegi, "Preliminary Data on the Bog Surface Wetness from the Sirok Nyírjes-tó Peat Bog, Mátra Mts, Hungary," Central European Geology, Vol. 53, No. 1, 2010, pp. 43-65. doi:10.1556/CEuGeol.53.2010.1.3

[10] K. Náfrádi, "Régészeti Lelőhelyek Szenült Faanyagának Határozása és Értékelése a Geoarcheológiai Kutatásokban," SZTE TTIK Földtani és Öslénytani Tanszék, PhD dolgozat, Szeged, 2012.

[11] Z. Szelepcsényi, H. Breuer, F.Ács and I. Kozma, "Biofizikai Klímaklasszifikációk (1. Rész: A Módszerek Bemutatása)," Légkör, Vol. 54, No. 3, 2009, pp. 21-26.

[12] Z. Szelepcsényi, H. Breuer, F.Ács and I. Kozma, "Biofizikai Klímaklasszifikációk (1. Rész: A Módszerek Bemutatása)," Légkör, Vol. 54, No. 4, 2009, pp. 18-23.

[13] B. Aaby, "Cyclic Climatic Variations in Climate over the Past 5500 Yrs Reflected in Raised Bogs," Nature, Vol. 263, No. 5575, 1976, pp. 281-284. doi:10.1038/263281a0

[14] K. E. Barber, "Peatland Records of Holocene Climate Change," In: S. A. Elias, Ed., Encyclopedia of Quartermary Science, Elsevier, Vol. 3, 2007, pp. 1883-1894. doi:10.1016/B0-44-452747-8/00383-5

[15] P. D. M. Hughes, D. Mauquoy, K. E. Barber and P. G. Langdon, "Mire Development Pathways and Palaeoclimatic Records from a Full Holocene Peat Archive at Walton Moss, Cumbria, England," The Holocene, Vol. 10, No. 4, 2000, pp. 465-479. doi:10.1191/095968300675142023

[16] K. E. Barber and P. G. Langdon, "Peat Stratigraphy and Climate Change," In: D. R. Brothwell and A. M. Pollard, Eds., Handbook of Archaeological Sciences, Wiley, Chicester, 2001, pp. 155-166.

[17] K. E. Barber and D. Charman, "Holocene Palaeoclimate Records from Peatlands,” In: A. Mackay, R. Battarbee, J. Birks and F. Oldfield, Eds., Global Change in the Holocene, Hodder Arnold, London, 2005, pp. 210-226.

[18] H. H. Birks, "Plant Macrofossil Introduction," In: S. A. Elias, Ed., Encyclopedia of Quaternary Science, Elsevier, Vol. 3, 2007, pp. 2266-2288. doi:10.1016/B0-44-452747-8/00215-5 
[19] D. Mauquoy and B. van Geel, "Mire and Peat Macros," In: S. A. Elias, Ed., Encyclopedia of Quatermary Science, Elsevier, Vol. 3, 2007, pp. 2315-2336. doi:10.1016/B0-44-452747-8/00229-5

[20] K. E. Barber, F. M. Chambers, D. Maddy and J. Brew, "A Sensitive High Resolution Record of the Holocene Climatic Change from a Raised Bog in Northern England," The Holocene, Vol. 4, No. 2, 1994, pp. 198-205. doi: $10.1177 / 095968369400400209$

[21] D. Mauquoy and K. Barber, "A Replicated 3000 yr Proxy-Climate Record from Coom Rigg Moss and Felicia Moss, The Border Mires, Northern England," Journal of Quaternary Science, Vol. 14, No. 3, 1999, pp. 263-275. doi:10.1002/(SICI)1099-1417(199905)14:3<263::AID-JQ S445>3.0.CO;2-W

[22] K. E. Barber, D. Maddy, N. Rose, A. C. Stevenson, R. Stoneman and R. Thompson, "Replicated Proxy-Climate Signals over the Last $2000 \mathrm{yr}$ from Two Distant UK Peat Bogs: New Evidence for Regional Palaeoclimate Teleconnections," Quaternary Science Reviews, Vol. 19, No. 6, 2000, pp. 481-487. doi:10.1016/S0277-3791(99)00102-X

[23] J. Blackford, "Palaeoclimatic Records from Peat Bogs," Trends in Ecology and Evolution, Vol. 15, No. 5, 2000, pp. 193-198. doi:10.1016/S0169-5347(00)01826-7

[24] K. E. Barber, "Peatland Records of Holocene Climate Change,” In: S. A. Elias, Ed., Encyclopedia of Quartermary Science, Elsevier, Vol. 3, 2007, pp. 1883-1894. doi:10.1016/B0-44-452747-8/00383-5

[25] M. Väliranta, A. Korhola, H. Seppä, E. Tuittila, K. Sarmaja-Korhonen, J. Laine and J. Alm, "High Resolution Reconstruction of Wetness Dynamics in Southern Boreal Raised Bog, Finland, during the Late Holocene: A Quantitative Approach," The Holocene, Vol. 17, No. 8, 2007, pp. 1093-1107.

[26] K. Buczkó, E. K. Magyari, P. Bitusik and A. Wacnik, "Review of Dated Late Quaternarypalaeolimnological Records in the Carpathian Region, East-Central Europe," Hydrobiologia, Vol. 631, No. 1, 2009, pp. 3-28.

[27] Á. Boros, "Bryogeographie und Bryoflora Ungarns," Akadémiai Kiadó, Budapest, 1968, 466 p.

[28] E. Szurdoki and J. Nagy, "Sphagnum Dominated Mires and Sphagnum Occurrences of North-Hungary," Folia Historico Naturalia Musei Matrensis, Vol. 26, No. 1, 2002, pp. 67-84.

[29] W. Koppen, "Die Klimate der Erde. Grundriss der Klimakunde," Walter de Gruyter, 1923.

[30] Z. Dobosi and L. Felméry, "Klimatológia," Tankönyvkiadó, Budapest, 1977, 496 p.

[31] L. R. Holdridge, "Determination of World Formulations from Simple Climatic Data," Science, Vol. 105, No. 2727 , 1947, pp. 367-368. doi:10.1126/science.105.2727.367

[32] L. R. Holdridge, "Life Zone Ecology," Tropical Science Center, San Jose, 1967.

[33] Z. Szelepcsényi, “A Kárpát-Medence Éghajlata a XX. Században Holdridge Életforma Rendszere Alapján," OFKD dolgozat. XIII. Országos Felsőoktatási Környezettudományi Diákkonferencia, Veszprém, 2012, 33 p.
[34] T. D. Mitchell, T. R. Carter, P. D. Jones, M. Hulme and M. New, "A Comprehensive Set of High-Resolution Grids of Monthly Climate for Europe and the Globe: The Observed Record (1901-2000) and 16 Scenarios (20012100)," Tyndall Working Paper 55, Tyndall Centre, UEA, Norwich, 2010.

http://www.tyndall.ac.uk/sites/default/files/wp55.pdf

[35] I. Máthé and M. Kovács, “A Mátra Tőzegmohás Lápja," Botanikai Közlemények, Vol. 47, No. 3-4, 1958, pp. 323331.

[36] E. Szurdoki, "Magyarországi Tőzegmohafajok Elterjedése és Egyes Fajok Vízkémiai Igényének Vizsgálata (Distribution of Hungarian Peat Mosses and Investigation of Water Chemical Relation of Some Species)," PhD Thesis, L. Eötvös University, Budapest, 2005.

[37] K. Penksza, G. Turcsányi and M. Kovács, "A Siroki Nyírjes-tó Tõzegmohalápjának Elemkatasztere (Element Concentration Cadasters of Peat Profiles in Nyírjes Bog Near Sirok in Hungary)," Botanikai Közlemények, Vol. 81, No. 1, 1994, pp. 29-41.

[38] P. C. Jowsey, "An Improved Peat Sampler," New Phytologist, Vol. 65, No. 2, 1966, pp. 245-248. doi:10.1111/j.1469-8137.1966.tb06356.x

[39] B. Aaby and G. Digerfeldt, "Sampling Techniques for Lakes and Bogs", In: B. E. Berglund, Ed., Handbook of Holocene Palaeoecology and Palaeohydrology, John Wiley and Sons Ltd., Hoboken, 1986, pp. 181-194.

[40] K. D. Bennett, "PSIMPOLL-A QuickBASIC Program That Generates PostScript Page Description of Pollen Diagrams.-INQUA Commission for the Study of the Holocene: Working Group on Data Handling Methods," Newsletter, Vol. 8, No. 1, 1992, pp. 11-12.

[41] J. Troels-Smith, "Karakterisering af Lose Jordater," Danmarks Geologiske Undersogelse, Vol. 4, No. 3, 1955, pp. 1-73.

[42] B. Weninger, O. Jöris and U. Danzeglocke, "CalPal-2007. Cologne, Radiocarbon Calibration \& Palaeoclimate Research Package," 2008. http://www.calpal.de

[43] G. Jakab, P. Sümegi and E. Magyari, "A New Palaeobotanical Method for the Description of Late Quarternary Organic Sediments (Mire-Development Pathways and Palaeoclimatic Records from S Hungary)," Acta Geologica Hungarica, Vol. 47, No. 4, 2004, pp. 1-37. doi:10.1556/AGeol.47.2004.4.4

[44] S. Jacomet and A. Kreuz, "Archaobotanik. Aufgaben, Methoden und Ergebnisse Vegetations und Agrargeschichtlicher Forschung," Ulmer, Stuttgart, 1999.

[45] F. Gyulai, "Archaeobotanika. A Kulturnóvenyek Tórtenete a Karpat-Medenceben a Regeszeti Nóvenytani Yizsgalatok Alapjan (Archaeobotany. The History of Cultivated Plants on the Basis of Archaeological Plant Remains in the Carpathian Basin)," Jószóveg Miihely, Budapest, 2001.

[46] E. Asouti and P. Austin, "Reconstructing Woodland Vegetation and Its Exploitation by Past Societies, Based on the Analysis and Interpretation of Archaeological Wood Charcoal Macro-Remains," Environmental Archaeology, Vol. 10, No. 1, 2005, pp. 1-18. 


\section{doi:10.1179/146141005790083867}

[47] L. Chabal, L. Fabre, J. F. Terral and L. Thery-Parisot, "L'Anthracologie," In: L. Chabal, S. Crozat, L. Fabre, F. Guibal, P. Marinval, H. Richard, J. F. Terral and I. Thery, Eds., Bourauin-Mignot C., Brochier J.E., La Botaniaue, Paris, 1999, pp. 43-104.

[48] C. A. Keepax, "Charcoal Analysis with Particular Reference to Archaeological Sites in Britain," Unpublished PhD Thesis, University of London, London, 1988.

[49] S. Sarkany, "A Fak Osszehasonlito Szovettani Vizsgalata Kulfoldon es Hazankban (Comparative Wood Anatomical Analysis of Trees in Hungary and Abroad)," Botanikai Közlemények, Vol. 35, No. 5-6, 1938, pp. 296-309.

[50] P. Greguss, “A Kozepeuropai Lomblevelu Fak es Cserjek Meghatarozasa Szovettani Alapon (Wood Anatomical identification of Central European Trees and Shrubs)," Orszagos Magyar Termeszettudomanyi Muzeum, Budapest, 1945. (in Hungarian)

[51] P. Greguss, "Xylotomy of the Living Conifers," Akademia Kiadó, Budapest, 1972

[52] F. H. Schweingruber, "Mikroskopische Holzanatomie Birmensdorf, Bidgenóssiche Forschungsantalt fur Wald," Schnee und Landchaft, 1990.

[53] G. Grosse-Brauckmann, W. Haussner and K. Mohr, "Über Eine Kleine Vermoorung im Odenwald, Ihre Ablagerungen und Ihre Entwicklung der Umgebenden Kulturlandschaft," Kulturtechnik und Flurbereinigung, Vol. 14, 1973, pp. 132-143.

[54] E. Rybnícková, "Die Entwicklung der Vegetation und Flora im Südlichen Teil der Böhmisch-Mährischen Höhe während des Spätglacial und Holozäns," Vegetace CSSR, Vol. 7, 1974, pp. 1-163.

[55] K. Rybnícek and E. Rybnícková, "The Origin and Development of Waterlogged Meadows in the Central Part of the Sumava Foothills," Folia Geobotanica \& Phytotaxonomica, Vol. 9, No. 1, 1974, pp. 45-70.

[56] K. Lájer, "Bevezetés a Magyarországi Lápok VegetációÖkológiájába (Introduction to the Vegetation Ecology of the Peatbogs in Hungary)," Tilia, Vol. 6, 1998, pp. 84238.

[57] A. Borhidi and A. Sánta (Eds) "Vörös Könyv Magyarország Növénytársulásairól 1-2 (Red Book of Plant Communities in Hungary)," Természetbúvár Alapítvány Kiadó, Budapest, 1999, pp. 362-404.

[58] P. Sümegi, S. Gulyás and G. Jakab, "Holocene Paleoclimatic and Paleohydrological Changes in Lake Balaton as Inferred from a Complex Quantitative Environmental Historical Study of a Lacustrine Sequence of the Szigliget Embayment," Documenta Praehistorica, Vol. 35, No. 1, 2008, pp. 33-43.

[59] P. Sümegi, G. Jakab, P. Majkut, T. Törõcsik and Cs. Zatykó, "Middle Age Paleoecological and Paleoclimatological Reconstruction in the Carpathian Basin," Idõjárás, Vol. 113, No. 4, 2009, pp. 265-298.

[60] E. Magyari, K. Buczkó, G. Jakab, M. Braun, Zs. Szántó, M. Molnár, Z. Pál and D. Karátson, "Holocene Palaeohydrology and Environmental History in the South Harghita
Mountains, Romania," Földtani Közlöny, Vol. 136, No. 2, 2006, pp. 249-284

[61] E. K. Magyari, K. Buczkó, G. Jakab, M. Braun, Z. Pál and D. Karátson, "Palaeolimnology of the Last Eastern Carpathian Crater Lake-A Multiproxy Study of Holocene Hydrological Changes," Hydrobiologia, Vol. 631, No. 1, 2009, pp. 29-63. doi:10.1007/s10750-009-9801-1

[62] P. Sümegi, “The Sediment Sequence from Mezõlak,” In: Cs. Zatykó, I. Juhász and P. Sümegi, Eds., Environmental Archaeology in Transdanubia (Hungary), Varia Archaeologica Hungarica, Budapest, 2007, pp. 403-404.

[63] U. E. Joerin, K. Nicolussi, A. Fischer, T. F. Stocker and C. Schlüchter, "Holocene Optimum Events Inferred from Subglacial Sediments at Tschierva Glacier, Eastern Swiss Alps," Quaternary Science Reviews, Vol. 27, No. 3-4, 2008, pp. 337-350. doi:10.1016/j.quascirev.2007.10.016

[64] R. Cheddadi, G. Yu, J. Guiot, S. P. Harrison and I. C. Prentice, "The Climate of Europe 6000 Years Ago," Climate Dynamics, Vol. 13, No. 1, 1997, pp. 1-9. doi: $10.1007 / \mathrm{s} 003820050148$

[65] B. A. S. Davis, S. Brewer, A. C. Stevenson, J. Guiot and Data Contributors, "The Temperature of Europe During the Holocene Reconstructed from Pollen Data," Quarternary Science Reviews, Vol. 22, No. 15-17, 2003, pp. 1701-1716. doi:10.1016/S0277-3791(03)00173-2

[66] E. Magyari, P. Sümegi, M. Braun, G. Jakab and M. Molnár, "Retarded Wetland Succession: Anthropogenic and Climatic Signals in a Holocene Peat Bog Profile from NorthEast Hungary," Journal of Ecology, Vol. 89, No. 6, 2001, pp. 1019-1032. doi:10.1111/j.1365-2745.2001.00624.X

[67] E. K. Magyari, J. C. Chapman, D. G. Passmore, J. R. M. Allen, J. P. Huntley and B. Huntley, "Holocene Persistence of Wooded Steppe in the Northern Great Hungarian Plain," Journal of Biogeography, Vol. 37, No. 5, 2010, pp. 915-935. doi:10.1111/j.1365-2699.2009.02261.x

[68] M. Magny, U. Leuzinger, S. Bortenschlager and J. N. Haas, "Tripartite Climate Reversal in Central Europe 5600-5300 Years Ago," Quaternary Research, Vol. 65, No. 1, 2006, pp. 3-19. doi:10.1016/j.yqres.2005.06.009

[69] Y. Iizuka, T. Hondoh and Y. Fujii, "Antarctic Sea Ice Extent during the Holocene Reconstructed from Inland Ice Core Evidence," Journal of Geophysical Research, Vol. 113, No. D15, 2008, in Press. doi:10.1029/2007JD009326

[70] R. B. Alley, P. A. Mayewski, P. T. Sowers, M. Stuiver, K. C. Taylor and P. U. Clark, "Holocene Climatic Instability: A Prominent, Widespread Event 8200 yr Ago," The Geological Society of America, Vol. 25, No. 6, 1997, pp. 483-486. doi:10.1130/0091-7613(1997)025<0483:HCIAPW $>2.3$.C $\underline{\mathrm{O} ; 2}$

[71] R. B. Alley and A. M. Ágústsdóttir, "The 8k Event: Cause and Consequences of a Major Holocene Abrupt Climate Change," Quaternary Science Reviews, Vol. 24, No. 10-11, 2005, pp. 1123-1149. doi:10.1016/j.quascirev.2004.12.004

[72] G. Bond, W. Showers, M. Cheseby, R. Lotti, P. Almasi, P. deMenocal, P. Priore, H. Cullen, I. Hajdas and G. Bonani, "A Pervasive Millenial-Scale Cycle in North Atlantic 
Holocene and Glacial Climates," Science, Vol. 278, No. 5341, 1997, pp. 1257-1266.

doi:10.1126/science.278.5341.1257

[73] A. Nesje and S. O. Dahl, "The Greenland 8200 Cal. yr BP Event Detected in Loss-On-Ignition Profiles in Norwegian Lacustrine Sediment Sequences," Journal of Quarternary Science, Vol. 16, No. 2, 2001, pp. 155-166. doi:10.1002/jqs.567

[74] M. Magny, "Reconstruction of Holocene Lake-Level Changes in the Jura (France): Methods and Results," In: S. P. Harrison, B. Frenzel, U. Huckried and M. Weiss, Eds., Palaeohydrology as Reflected in Lake-Level Changes as Climatic Evidence for Holocene Times, Paläoklima-forSchung, 1998, pp. 67-85.

[75] M. Magny and P. Schoellammer, "Lake-Level Fluctuations at Le Locle, Swiss Jura, from the Younger Dryas to the Mid-Holocene: A High-Resolution Record of Climate Oscillations during the Final Deglaciation," Géographie Physique et Quaternaire, Vol. 53, No. 2, 1999, pp. 183197. doi:10.7202/005693ar

[76] M. Magny, C. Miramont and O. Sivan, "Assessment of Climate and Antropogenic Factors on Holocene Mediterranean Vegetation in Europe on the Basis of Palaeohydrological Records," Palaeogeography, Palaeoclimatology, Palaeoecology, Vol. 186, No. 1-2, 2002, pp. 47-59. doi:10.1016/S0031-0182(02)00442-X

[77] J. N. Haas, I. Richoz, W. Tinner and L. Wick, "Synchronous Holocene Climatic Oscillations Recorded on the Swiss Plateau and at the Timberline in the Alps," The Holocene, Vol. 8, No. 3, 1998, pp. 301-304. doi:10.1191/095968398675491173

[78] A. Feurdean, S. Klotz, V. Mosbrugger and B. Wohlfarth, "Pollen-Based Quantitative Reconstructions of Holocene Climate Variability in NW Romania," Palaeogeography, Palaeoclimatology, Palaeoecology, Vol. 260, No. 3-4, 2008, pp. 494-504. doi:10.1016/j.palaeo.2007.12.014

[79] C. Schnitchen, E. Magyari, B. Tóthmérész, I. Grigorszky and M. Braun, "Micropaleontological Observations on a Sphagnum Bog in East Carpathian Region-Testate Amoebae (Rhizopoda: Testacea) and Their Potential Use for Reconstruction of Micro- and Macroclimatic Changes," Hydrobiologia, Vol. 506, No. 1-3, 2003, pp. 45-49. doi:10.1023/B:HYDR.0000008553.82554.c2

[80] G. Jakab and P. Sümegi, "The Vegetation History of Baláta-Tó,” In: I. E. Juhász, Cs. Zatykó, P. Sümegi, Eds., Environmental History of Transdanubia, Varia Archaeologica Hungarica, Budapest, 2007, pp. 251-254.

[81] Cs. Schnitchen, D. J. Charman, E. Magyari, M. Braun, I. Grigorszky, B. Tóthmérész, M. Molnár and Zs. Szántó, "Reconstructing Hydrological Variability from Testate Amoebae Analysis in Carpathian Peatlands," Journal of Paleolimnology, Vol. 36, No. 1, 2006, pp. 1-17. doi:10.1007/s10933-006-0001-y

[82] Gy. Györffy and B. Zólyomi, "A Kárpát-Medence és Etelköz Képe egy Évezred Elõtt (The People of the Carpathian Basin and Etelköz 1000 Years Ago)," In: Gy. Györffy, L. Kovács, Eds., Honfoglalás és Régészet (Hungarian Conquest and Archaeology), Balassi Kiadó, Budapest, 1994, pp. 13-37.
[83] Gy. Györffy, "Hová Lettek az Avarok (Where did the Avars Go)?" História, Vol. 17, No. 3, 1995, pp. 3-9.

[84] A. Kiss, "Weather Events during the First Tartar Invasion in Hungary (1241-42)," Acta Geographica Szegediensis, Vol. 37, 2000, pp. 149-156.

[85] A. Kiss, "Ecce, in Hyemis Nivis et Glaciei Habundantia Supervenit-Idõjárás, Környezeti Krízis és a Tatárjárás (Meteorology, Environmental Crisis and the Invasion of the Mongols)," In: B. Nagy, Ed., Tatárjárás (Invasion of the Mongols), Osiris Kiadó, Budapest, 2003, pp. 439-452.

[86] C. Pfister, "Wetternachhersage: 500 Jahre Klimavariationen und Naturkatastrophen (1496-1995)," Haupt, Bern, 1999, $304 \mathrm{p}$.

[87] C. Pfister and R. Brázdil, "Climatic Variability in Sixteenth-Century Europe and Its Social Dimension: A Synthesis," Climatic Change, Vol. 43, No. 1, 1999, pp. 5-53. doi:10.1023/A:1005585931899

[88] R. S. Bradley, M. K. Hughes and H. F. Diaz, "Climate in Medieval Time," Science, Vol. 302, No. 5644, 2003, pp. 404-405. doi:10.1126/science.1090372

[89] D. Mauquoy, T. Engelkes, M. H. M. Groot, F. Markesteijn, M. G. Oudejans, J. van der Plicht and B. van Geel, "High-Resolution Records of Late Holocene Climate Change and Carbon Accumulation in Two Northwest European Ombrotrophic Peat Bogs," Palaeogeography, Palaeoclimatology, Palaeoecology, Vol. 186, No. 3-4, 2002. pp. 275-310. doi:10.1016/S0031-0182(02)00513-8

[90] I. Popa and Z. Kern, "Long-Term Summer Temperature Reconstruction Inferred from Tree-Ring Records from the Eastern Carpathians," Climate Dynamics, Vol. 32, No. 7-8, 2009, pp. 1107-1117. doi:10.1007/s00382-008-0439-x

[91] M. Blaauw, B. van Geel and J. van der Plicht, "Solar Forcing of Climatic Change during the Mid-Holocene: Indicators from Raised Bogs in The Netherlands, The Holocene, Vol. 14, No. 1, 2004, pp. 35-44. doi:10.1191/0959683604hl687rp

[92] K. Schoning, D. J. Charman and S. Wastegard, "Reconstructed Water Tables from Two Ombrotrophic Mires in Eastern Central Sweden Compared with Instrumental Meteorological Data," The Holocene, Vol. 15, No. 1, 2005, pp. 111-118. doi:10.1191/0959683605hl772rp

[93] D. J. Charman, K. E. Barber, M. Blaauw, P. G. Langdon, D. Mauquoy, T. J. Daley, P. D. M. Hughes and E. Karofeld, "Climate Drivers for Peatland Palaeoclimate Records," Quaternary Science Reviews, Vol. 28, No. 19-20, 2009, pp. 1811-1819. doi:10.1016/j.quascirev.2009.05.013

[94] G. T. Swindles, A. Blundell, H. M. Roe and V. A. Hall, "A 4500-Year Proxy Climate Record from Peatlands in the Noth of Ireland: The Identification of Widespread Summer 'Drought Phases'?" Quaternary Science Reviews, Vol. 29, No.13-14, 2010, pp. 1577-1589. doi:10.1016/j.quascirev.2009.01.003

[95] D. J. Charman, "Summer Water Deficit Controls on Peatland Water Table Changes: Implications for Holocene Palaeoclimate Reconstructions," The Holocene, Vol. 17, No. 2, 2007, pp. 217-227. doi:10.1177/0959683607075836 